\title{
NOTCH4 wt Allele
}

National Cancer Institute

\section{Source}

National Cancer Institute. NOTCH4 wt Allele. NCI Thesaurus. Code C51564.

Human NOTCH4 wild-type allele is located in the vicinity of $6 \mathrm{p} 21.3$ and is approximately $29 \mathrm{~kb}$ in length. This allele, which encodes neurogenic locus notch homolog protein 4 protein, is involved in receptor-ligand interactions and may play a role in vascular, renal and hepatic development. 